J. Clin. Chem. Clin. Biochem.

Vol. 18, 1980, pp. 257-270

\title{
Magnesium Metabolism: A Review
}

\author{
By $H$. Ebel
}

Institut für Klinische Physiologie and

T. Günther

Institut für Molekularbiologie und Biochemie, Freie Universität Berlin

(Received May 30/October 11, 1979)

Summary: The main literature concerning the physiology and biochemistry as well as the pathophysiology and pathobiochemistry of magnesium is reviewed, including:

Distribution and physico-chemical state of magnesium in the extracellular and intracellular fluid as well as in the subcellular organelles (membranes, mitochondria, microsomes, ribosomes).

Intestinal resorption, transport across membranes and excretion by the kidney.

Hormonal regulation of magnesium distribution and its clinical disturbances.

Biochemical mechanism and the clinical effects of hypo- and hypermagnesemia.

\section{Magnesium-Stoffwechsel: Eine Übersicht}

Zusammenfassung: Die wichtigsten Arbeiten über die Physiologie und Biochemie sowie Pathophysiologie und Pathobiochemie des Magnesiums werden dargestellt.

Die Darstellung bezieht sich im wesentlichen auf:

Die Verteilung und den physikalisch-chemischen Zustand des $\mathrm{Mg}$ in der extrazellulären und intrazellulären Flüssigkeit und in den Zellorganellen (Membranen, Mitochondrien, Mikrosomen, Ribosomen).

Die Resorption im Darm, Transport durch Membranen und die Ausscheidung durch die Niere.

Die hormonale Regulation der Mg-Verteilung und ihre klinischen Störungen.

Biochemische Mechanismen und klinische Erscheinungen bei Hypo- und Hypermagnesiämie.

\section{Introduction}

Magnesium is one of the most vital elements of the body. It activates about 300 enzymes and is involved in the regulation of cellular permeability and neuromuscular excitability. Probably magnesium deserves more clinical attention than is usually given. This review is chiefly concerned with the fundamentals of magnesium metabolism and the related clinical aspects.

\section{Magneșiumm analysis}

Several methods are available for the determination of magnesium. At present atomic absorption spectrometry is the most convenient method, both in clinical chemistry and in research. Easy to handle, with a high sensitivity and specificity for magnesium, the method is relatively precise. Spectrophotometric determination of magnesium with dyes of the carboxyanilide type or methyl-thymol- 
blue yields values different from atomic absorption spectrometry. At magnesium concentrations above $0.86 \mathrm{mmol} / 1$ the colorimetric methods give higher values and below $0.86 \mathrm{mmol} / 1$ smaller values than are obtained with atomic absorption spectrometry. The formerly most popular titan yellow method should no longer be used, since the Mg-dye complex is unstable and the results show a considerable variance (1).

Other methods of magnesium determination have been introduced for special purposes. In renal physiology, the sample volume obtained by micropuncture is in the range of $\mathrm{nl}$ and the magnesium content to be determined in the pmol range. Electron probe analysis (2) and helium glow photometry (3) have been successfully used. More recently a fluorometric method with $\mathrm{N}^{\prime} \mathrm{N}^{\prime}$-bis-salicylidene $2^{\prime} 3$ diaminobenzofuran [SABF] (4) has been adapted for this ultramicro range (5). However, all the methods mentioned have some disadvantages. The instruments for electron probe analysis and helium glow photometry can only be operated by an experienced specialist. The SABF method is hampered by the interference of phosphate.

\section{Distribution of magnesium in the organism}

The ideal male body with a weight of $70 \mathrm{~kg}$ contains $1.18 \mathrm{~kg}$ calcium, $146 \mathrm{~g}$ potassium, $104 \mathrm{~g}$ sodium and $24 \mathrm{~g}$ magnesium (6). Approximately one half of the total magnesium content is in bones, three quarters of this are adsorbed to apatite. This magnesium fraction is in equilibrium with ionized magnesium of the extracellular fluid and can be readily mobilized in a state of magnesium deficiency. The ability to mobilize bone magnesium decreases with increasing age. About $95 \%$ of the other magnesium is localized in the intracellular space. After potassium, magnesium is the most abundant intracellular element. For literature see Hänze (6).

In an investigation with 5100 patients, serum magnesium was determined routinely by atomic absorption spectrometry. A normal value of $0.89 \pm 0.08 \mathrm{mmol} / 1( \pm 1 \mathrm{SD})$ was found. $90 \%$ of the values fell in the range between 0.75 and $1.0 \mathrm{mmol} / 1$ (7). A compilation of normal magnesium values in serum obtained with different methods such as complexometric titration, fluorometry with 8-hydroxyquinoline and flame photometry was published recently (8). The magnesium content of the human organs varies between 3 and $9 \mathrm{mmol} / \mathrm{kg}$ wet.weight $(9,10)$. As can be seen in table 1 , the highest non-osseous magnesium content can be found in muscle and heart. Values for other mammals are not different from those for humans (9).

The physicochemical state of plasma magnesium in man is listed in table 2 . As can be seen, $55 \%$ of magnesium is "free", i.e. in the ionized form. $32 \%$ of magnesium is protein bound, mostly to albumin. The remaining mag-
Tab. 1. Mg content of various human organs. $\mathrm{a}=$ data according to Walser (9). $\mathrm{b}=$ data according to lyengar et al. (10).

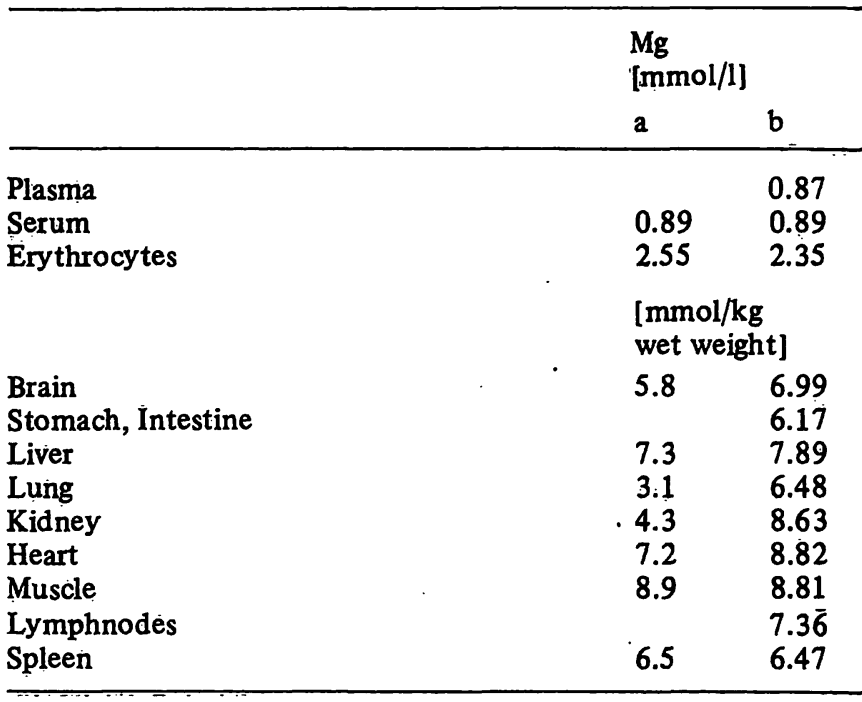

Tab. 2. Physico-chemical state of magnesium in plasma according to the data of Walser (9).

Protein (Albuminin) bound magnesium $32 \%$

Free magnesium $55 \%$

$\mathrm{MgHPO}_{4}$ $3 \%$

$\mathrm{Mg}$ citrate $4 \%$

Other $\mathrm{Mg}$-complexes $6 \%$

Tab. 3. Subcellular distribution of magnesium in rat liver. The references are a) Thiers \& Vallee (12), b) Griswold \& Pace (11), c) George \& Heaton (13), normal diet; d) George \& Heaton, magnesium deficient diet (13).

\begin{tabular}{|c|c|c|c|c|c|c|}
\hline Magnesium & $\begin{array}{l}{[\mathrm{mmol} /} \\
\mathrm{g} \mathrm{N}]\end{array}$ & $\begin{array}{l}\text { [\% of } \\
\text { total } \\
\mathrm{Mg}]\end{array}$ & $\begin{array}{l}\text { [mmol/ } \\
\mathrm{g} \mathrm{N} \text { ] }\end{array}$ & $\begin{array}{l}\text { [\% of } \\
\text { total } \\
\mathrm{Mg}]\end{array}$ & $\begin{array}{l}{[\mathrm{mmol} /} \\
\mathrm{g} \mathrm{N}]\end{array}$ & $\begin{array}{l}\text { [mmol/ } \\
\mathrm{g} \mathrm{N}]\end{array}$ \\
\hline & a & a & $\mathrm{b}$ & b & c & d \\
\hline $\begin{array}{l}\text { Nuclei } \\
\text { Mito- } \\
\quad \text { chondria }\end{array}$ & $\begin{array}{l}0.345 \\
0.424\end{array}$ & $\begin{array}{l}47.8 \\
17.4\end{array}$ & $\begin{array}{l}0.334 \\
0.294\end{array}$ & $\begin{array}{l}13.4 \\
21.8\end{array}$ & $\begin{array}{l}0.263 \\
0.153\end{array}$ & $\begin{array}{l}0.325 \\
0.140\end{array}$ \\
\hline $\begin{array}{l}\text { Microsomes } \\
\text { Supernatant } \\
\text { [Cytosol] }\end{array}$ & $\begin{array}{l}0.407 \\
0.218\end{array}$ & $\begin{array}{l}13.7 \\
19.2\end{array}$ & $\begin{array}{l}0.442 \\
0.244\end{array}$ & $\begin{array}{l}48 \\
12.8\end{array}$ & $\begin{array}{l}0.374 \\
0.210\end{array}$ & $\begin{array}{l}0.370 \\
0.201\end{array}$ \\
\hline
\end{tabular}

nesium is complexed with phosphate, citrate and other agents (9).

Within the cell, magnesium is not distributed homogeneously. In table 3 , the magnesium content of various subcellular fractions of rat liver is summarized. Different results were obtained, depending on the thoroughness of homogenization. It seems that most of the cellular magnesium is bound to microsomes $(11,12,13)$. Interestingly, the magnesium content of mitochondria and the amount of mitochondria per cell is reduced after magnesium deprivation (13).

Even within a single cell fraction, the distribution of magnesium is not homogeneous. In rat livet mito. 
chondria, $4 \%$ of the total magnesium content is in the outer membrane, $50 \%$ in the intermembraneous compartment, $5 \%$ in the inner membrane and $41 \%$ in the matrix (14). The high magnesium content in the intermembranous compartment is explained by a high magnesium binding capacity of certain proteins. One protein with a molecular weight of 150000 daltons binds $300 \mathrm{nmol} / \mathrm{mg}$ protein with a dissociation constant of $0.37 \mathrm{mmol} / 1$. Another protein with a molecular weight of 100000 daltons binds $20 \mathrm{nmol} / \mathrm{mg}$ protein with a dissociation constant of $1.0 \mu \mathrm{mol} / \mathrm{l}$ (15). In addition, magnesium is bound by phospholipids, not only in mitochondria but also in the endoplasmic reticulum. The nucleic acid of the endoplasmic reticulum and the ribosomes also binds magnesium. In the cytosol, ionized magnesium is in equilibrium with various magnesium complexes (see below).

\section{Biochemical functions of magnesium}

\section{Effect on enzyme reactions}

One of the main effects of magnesium is the activation of enzymes which is a result of its ability to form chelates. At present, approximately 300 enzymes are known that need magnesium for activation. One example is the group of enzymes involved in reactions with ATP. If one plots the catalytic activity of a magnesium-dependent enzyme as a function of $\mathrm{pMg}$, a symmetrical bell-shaped curve is obtained with a $\mathrm{pMg}$ optimum in the range of $\mathrm{pMg}=3$. (Analogous to the definition of $\left.\mathrm{pH}, \mathrm{pMg}=-\log \left[\mathrm{Mg}^{2+}\right]\right)$. Such a bell shaped curve (fig. 1) is the sum of two sigmoid curves: one curve expressing the activation and another the inhibition of the enzyme (16). Enzyme inhibition is caused by unspecific binding of magnesium to the enzyme protein, e.g. to the tyrosyl residues at high magnesium concentrations.

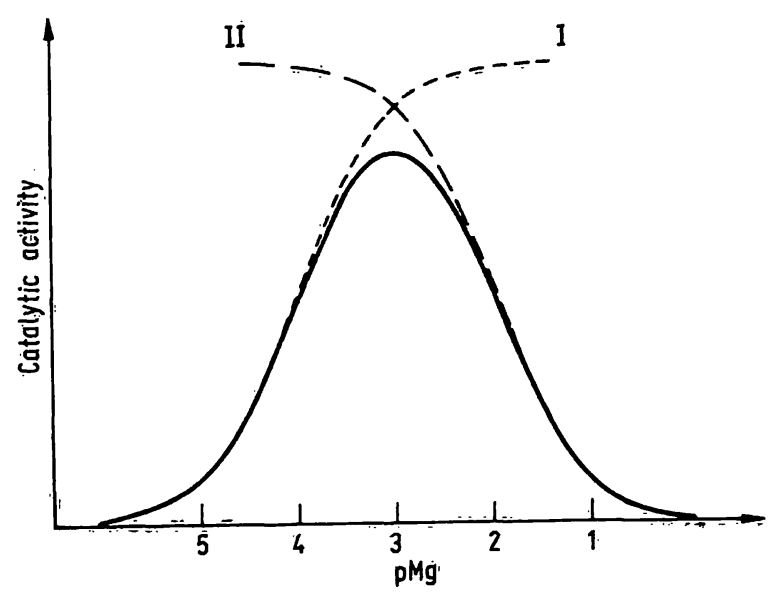

Fig. 1. Activity of a magnesium-dependent enzy me as a function of pMg. Curve I indicates the activation, curve II shows the inhibition of the enzyme as a function of $\mathrm{pMg}$.
The activation of enzymes by magnesium is thought to occur according to the following mechanisms:

$$
\begin{array}{rl}
1 . \mathrm{Mg}+\mathrm{S} \rightleftharpoons \mathrm{MgS} & \mathrm{E}=\text { enzyme } \\
& \mathrm{S}=\text { substrate } \\
\mathrm{MgS}+\mathrm{E} \rightleftharpoons \mathrm{MgES} \rightarrow \mathrm{MgP}+\mathrm{E} & \mathrm{P}=\text { reaction product }
\end{array}
$$

In this sequence, magnesium is reacting with the substrate. It reduces the high negative charge of the subtrate which is normally $\mathrm{ATP}^{4-}$. As a consequence $\mathrm{MgS}$, as the true substrate, is reacting with the enzyme. This type of reaction also occurs with hexokinase and phosphoglycerate kinase (18).

$$
\begin{aligned}
2 . \mathrm{Mg}+\mathrm{E} & \rightleftharpoons \mathrm{MgE} \\
\mathrm{MgE}+\mathrm{S} & \rightleftharpoons \mathrm{MgSE} \rightarrow \mathrm{MgE}+\mathrm{P}
\end{aligned}
$$

In this reaction sequence, magnesium first reacts with the enzyme. This is followed by a conformational change of the enzyme, resulting in its activation. Thereafter, the substrate is bound to the enzyme. Examples of this type of reaction are the enolase, pyruvate kinase, and pyrophosphatase (18). The binding of $\mathrm{S}$ to $\mathrm{MgE}$ can also be accomplished with participation of magnesium. In both types of reaction, magnesium facilitates the reaction by polarization as an additional effect (for review see Günther (19)). Also, a combination of both types of reaction is possible. In the $F_{1}$ ATPase reaction of $E$. coli, $\mathrm{Mg} \mathrm{ATP}$ is the substrate. In addition, the enzyme is activated by magnesium (20).

Another effect of magnesium is to change the equilibrium of a reaction; this arises when magnesium forms complexes with the substrate and reaction product, which have different stabilities; alternatively the free substrate and its magnesium complex may have different affinities for the enzyme.

\section{Reaction of magnesium with intracellular structures}

Magnesium and calcium form stable complexes with phospholipids that are an integral part of the cell membranes. For phosphatidylserine, the stability constant of magnesium is $2 \times 10^{4}(\mathrm{~mol} / \mathrm{l})^{-1}(21)$. The stability constant for Mg ATP is in the same range. Calcium forms complexes of similar stability with phosphatidylserine. No data are available for other membranelocated phospholipids. However, it can be assumed, that with regard to magnesium and calcium concentrations in the intra- and extracellular space, most of the phosphate groups in phospholipids are occupied with magnesium and calcium. On the cytoplasmic side of the plasma membrane, not only magnesium but also polyamines could be bound. The binding of divalent cations to the phospholipids decreases their mobility within the membrane, thus decreasing membrane fluidity (22). 
As a consequence, membrane permeability may be decreased and the reaction of a hormone-receptorcomplex of the cell membrane with a membranebound enzyme may be altered. In addition, the activity of membrane-bound, phospholipid-dependent enzymes should also be changed. Interestingly, in $E$. coli grown in magnesium deficient media, membrane permeability increased and the composition of phospholipids was changed (23). This defect could not be normalized by the addition of magnesium alone, but requires protein synthesis (24).

The binding of magnesium to nucleic acids by forming outer sphere complexes reduces the repelling action of the negatively charged phosphate groups. A crosslinking of contiguous nucleic acid helixes by magnesium is unlikely because of the relatively wide distance between two phosphate residues. However, any folding of a polynucleotide chain which brings two phosphate residues more closely together, may result in the formation of $\mathrm{Mg}^{2+}$ inner sphere complexes. Moreover, the presence of $\mathrm{Mg}^{2+}$ will favour the folding of polynucleotide chains. Thus the formation of the native tRNA conformation, which requires a very close folding of the nucleotide chain, is greatly facilitated by $\mathrm{Mg}^{2+}$ (25). For Example, one mol phenylalanine-t-RNA binds four moles of $\mathrm{Mg}^{2+}$ and two moles of spermine. Their exact location within the t-RNA molecule has been determined (26). Other nucleic acids, ribosomes and ribosomal RNA bind up to 0.5 magnesium/phosphate, depending on ionic strength and polyamine and magnesium concentrations (27). tRNA ${ }^{\text {fMet }}$ has a strong $\mathrm{Mg}^{2+}$ binding site $\left(\mathrm{K}=3 \cdot 10^{4}(\mathrm{~mol} / \mathrm{l})^{-1}\right)$ and weak binding sites with $\mathrm{K}=4 \cdot 10^{2}(\mathrm{~mol} / \mathrm{l})^{-1}(28)$. This explains why the formation of the initiation complex in protein synthesis also depends on magnesium ions (29). After removal of magnesium, the conformation of ribosomes is changed (30), and they disintegrate and disappear (31).

To summarize, it is evident that due to its additive actions on enzymes and cellular structures magnesium is involved in most reactions of carbohydrate, lipid, nucleic acid and protein metabolism. Therefore all energy producing reactions (oxidative phosphorylation) as well as all energy consuming reactions (contraction) are dependent on magnesium.

\section{Intracellular concentration of magnesium ions .}

The intracellular space is divided by membranes (endoplasmic reticulum, sarcoplasmic reticulum, mitochondria, golgi vesicles, lysosomes etc.) within several compartments. Transport and exchange of calcium and also magnesium takes place in these compartments. In addition, cations are concentrated near the surface of poly: anions and near the surface of electrically charged membranes (Donnan-effect). Therefore within the cytosol, the magnesium ion concentration may exhibit considerable local differences. The value for the intracellular magnesium ion concentration represents only an integral value.

The intracellular concentration of free and complexed magnesium has been evaluated by different methods:

1. Magnesium ion concentration has been calculated, taking into consideration a) the stability constants of the main intracellular magnesium chelators; $b$ ) the intracellular magnesium concentration; $c$ ) intracellular $\mathrm{pH}$, and d) intracellular ionic strength (32).

2. The magnesium-dependent equilibrium constant of a suitable enzymatic reaction (aconitate hydratase) was calculated from the intracellular concentration of the reaction components and compared with the magnesium dependence of the equilibrium constant in vitro (33).

3. The activation of the magnesium-dependent isocitric dehydrogenase by known magnesium concentrations has been compared with the activation by the unknown magnesium concentration of tissue extracts (34).

4. Magnesium ion activity has been determined directly in tissue extracts by a magnesium-sensitive electrode. The interference by sodium and potassium has been considered (35).

The values obtained with the different methods resulted in a magnesium ion concentration of about $10^{-3} \mathrm{~mol} / 1$ $(\mathrm{pMg}=3)$. This means that approximately $80 \%$ of total cellular magnesium is bound. Free and bound magnesium form a "magnesium buffer system" keeping the free magnesium ion concentration relatively constant (33, 36). At this pMg, most of the magnesium dependent enzymes are optimally activated or nearly so (19). This intracellular magnesium ion concentration is so low that polyamines may be involved in the functions of magnesium in protein synthesis (37).

The low intracellular magnesium-ion concentration prevents miscoding (38-40) and facilitates the action of the initiation and dissociation factors in protein synthesis (41-43).

\section{Magnesium transport}

In nongrowing cells and in most organs of adult animals, the transport rate of magnesium is low and difficult to measure by conventional chemical techniques. Therefore, the mechanism of magnesium transport has been frequently investigated using ${ }^{28} \mathrm{Mg}$. However, the use of ${ }^{28} \mathrm{Mg}$ was hampered by a) a short half life time of 21 hours, b) a relatively low specific activity, and c) limited availability. It has been shown in rabbits.and rats that after administration of ${ }^{28} \mathrm{Mg}$ the isotope was incorporated into all organs (44-46). The exchange of ${ }^{28} \mathrm{Mg}$ in liver, kidney and heart was rapid, while the turnover in muscle, brain and erythrocytes was relatively slow. For 
the isolated perfused heart, it has been found that $98 \%$ of the magnesium content was exchanged with the same rate constant. The exchange followed MIchaelis-Menten kinetics. The $K_{\mathrm{m}}$ value was $0.57 \mathrm{mmol} / 1$ (47). $\mathrm{KB}$ cells showed a similar behaviour. The $K_{\mathrm{m}}$ values averaged $0.1 \mathrm{mmol} / 1$. The ${ }^{28} \mathrm{Mg}$ exchange was specific and could not be inhibited by calcium. Inhibition of respiration by cyanide, of oxidative phosphorylation by $m$-chlorophenyl carbonylcyanide hydrazone (CCCP) and of $\left(\mathrm{Na}^{+}+\mathrm{K}^{+}\right)$. ATPase by ouabain decreased the exchange of ${ }^{28} \mathrm{Mg}$ (48). Analogous results have been obtained with $E$. coli $(49,50)$.

From these results it may be concluded that ${ }^{28} \mathrm{Mg}$ is taken up in an energy-dependent process by a "carrier" or a "channel". Since the magnesium transport of growing $E$. coli is genetically determined $(51,52)$ it may be assumed that magnesium transport is facilitated or controlled by a specific protein, at least in these cells. Whether the magnesium transport of nongrowing cells is an "active transport" cannot be decided at the moment. Under these conditions, the carrier-mediated exchange of magnesium does not result in net uptake, which is in contrast to the growing cells $(53,54)$. While growing bacteria concentrate magnesium against a gradient of up to 1:1000, the magnesium gradient of animal cells is approximately only $1: 3$.

Therefore, the intracellular magnesium ion concentration in animal cells is likely to be very similar to the extracellular concentration, so that there may be no significant magnesium gradient (33).

As already pointed out, magnesium is not only transported into the cell but is also transported within the cell into the different cellular organelles. In experiments with isolated mitochondria and endoplasmic or sarcoplasmic reticulum, the existence of magnesium transport has been demonstrated. Mitochondria showed an energy-dependent magnesium uptake $(55,56)$. The magnesium efflux of mitochondria was also dependent on respiration, which obviously is dependent on mitochondrial calcium turnover (57), for review see Bygrave (58). Microsomes and reconstituted phospholipid vesicles containing Ca-ATPase exchanged two calcium ions against one magnesium and two potassiums $(59,60)$.

In this case transport or release of magnesium is coupled to transport or release of calcium, at least in mitochondria and endoplasmic or sarcoplasmic reticulum. The cytosolic calcium concentration is changed considerably during these processes, which is important for regulation of muscular contraction and cellular metabolism (58). Since the intracellular magnesium is buffered, the cytosolic magnesium concentration will not be changed $(33,36)$. However, it cannot be excluded that the properties of mitochondria or endoplasmic reticulum are changed by release of magnesium.

\section{Magnesium uptake in the intestine}

The daily magnesium intake varies considerably. The main dietary sources of magnesium are green vegetables, meat and seafood. However, depending on the technique of cooking, large quantities of magnesium may be extracted into water and thus lost. Therefore, the data indicating an average daily intake of $15 \mathrm{mmol}$ magnesium must be regarded with caution. It is believed that the amount of magnesium absorbed by the gut depends on the amount of magnesium intake and is not affected by the needs of the body, either in hypomagnesemia or in hypermagnesemia. However, controversial results on the effect of hormones on intestinal magnesium uptake have been reported (see below). Clearly more systematic studies are needed to decide the question of whether the intestinal magnesium absorption is controlled by a homeostatic mechanism. For details see the review of Walser (9).

Intestinal magnesium uptake has been investigated preferentially in animals. As was found in rats with loops isolated in vivo, magnesium is absorbed throughout the whole intestine from the duodenum up to the colon. It is believed that in this species most of the magnesium uptake is located in the duodenum. The ileum and colon absorb less magnesium than the duodenum, but do not differ, one from the other $(61,62)$. In humans, isolated perfused jejunum and ileum take up approximately the same amount of magnesium (63).

At present it cannot be decided by which mechanism magnesium is absorbed in the intestine. Experiments on the relation of magnesium absorption to luminal magnesium concentration resulted in a nonlinear, saturable funcion in all species investigated. These were rat $(62,64,65)$, sheep (66), and human (63). Unfortunately no $K_{\mathrm{m}}$ values have been reported. This result may be interpreted to mean that magnesium is taken up by a "carrier" or a "channel" with limited capacity. However, it could also mean that magnesium is taken up by simple diffusion, which is reduced at higher magnesium concentrations by a limited magnesium permeability. Increasing $\mathrm{Mg}$ concentration decreases intestinal and renal tubular water permeability $(67,68)$. Evidence for magnesium uptake by "solvent drag" was obtained in the rat ileum. Magnesium uptake was strictly determined by the magnitude and direction of transepithelial water flux: sodium, urea and sugar stimulate the uptake of water and magnesium. Mannitol inhibits both processes (62). However, transepithelial magnesium transport takes place against a transmural potential difference (PD). In the rat ileum, the $P D$ is $+3 \mathrm{mV}$ in the absence and $+11 \mathrm{mV}$ in the presence of glucose $(62,69)$. In the rat colon the average PD is $23 \mathrm{mV}$, independently of glucose (62). In the sheep ileum, magnesium uptake occurs at a transmural PD of +10 to $+15 \mathrm{mV}(66,70)$. 
In order to analyse further the mechanisms of transepithelial magnesium transport, it would be necessary to calculate the magnesium equilibrium potential according to the Nernst equation on both the mucosal and the serosal side of the intestine. However, this would require data on the magnesium ion concentration of stool and within the cell, which are not available at present. In stripped mucosa of rat duodenum, the total magnesium content is $8.5 \mathrm{mmol} / \mathrm{kg}$ wet weight and the serum concentration is $0.95 \mathrm{mmol} / \mathrm{l}$ (71). Assuming 1) a water content of approximately $80 \%$ and 2 ) that $80 \%$ of the total magnesium is bound, the cellular magnesium ion concentration could be in the range of $1 \mathrm{mmol} / \mathrm{l}$ cell water. This value is in agreement with data determined for other tissues (33-35). At an expected magnesium ion concentration of $2 \mathrm{mmol} / \mathrm{l}$ stool water, the magnesium equilibrium potential on the mucosal side of the cell is in the range of $+9 \mathrm{mV}$. Since the measured mucosal transmembranal PD of rat ileum was approximately $-9 \mathrm{mV}(69)$, magnesium uptake could be passively driven by a total gradient of about $18 \mathrm{mV}$. This assumption would also be true for a higher content of ionized magnesium in stool. As a second step, magnesium is extruded from the cell and taken up from the blood. In serum the magnesium ion concentration should be in the range of $0.5 \mathrm{mmol} / \mathrm{l}$ at a total concentration of $0.95 \mathrm{mmol} / 1$. The calculated magnesium equilibrium potential would be approximately $-9 \mathrm{mV}$. However, since the measured serosal transmembranal PD of rat jejunum was $-20 \mathrm{mV}$, intracellular side negative (69), magnesium has to be transported against a potential of $11 \mathrm{mV}$. Thus, magnesium extrusion should be an active process. It has recently been demonstrated for the rumen epithelium of sheep that magnesium transport is dependent on metabolic energy (72). However, it must be stated that the calculation of the magnesium equilibrium potential is only tentative and is critically dependent on the intracellular magnesium ion concentration, which is not exactly known in this tissue. If the intracellular magnesium ion concentration exceeds 2.2 $\mathrm{mmol} / \mathrm{l}$, the equilibrium potential and measured PD would be approximately the same, and magnesium extrusion could be passive.

In several species, intestinal magnesium uptake is inhibited by calcium. This has been reported for loops of rat intestine perfused in vivo (73) and for sheep intestine (66). The inhibition of magnesium uptake may be caused by a decrease in membrane permeability induced by calcium or by competition of calcium and magnesium for the same carrier. Unfortunately no kinetic analysis has been reported by the investigators. It should be mentioned that in humans calcium exerted no effect on magnesium reabsorption in jejunum perfused in vivo (63).

Phosphate is an additional factor determining magnesium reabsorption. At normal magnesium intake magnesium reabsorption is decreased by the formation of insoluble magnesium phosphate complexes $(74,75)$. The fat content of the intestinal contents also influences magnesium absorption. It has long been known that in man, steatorrhea is associated with increased fecal losses of calcium and magnesium (76-80) which is likely to be due in part to fecal fatty acid magnesium soap formation. In more systematic studies with rats $(81)$ and new born infants $(82,83)$ it has been shown that the nature and quantity of fat intake determines magnesium reabsorption. When poorly absorbable fats consituted a large proportion of the diet, absorption of magnesium deçreased considerably.

\section{Renal magnesium excretion}

The kidney is the most important organ for regulation of magnesium metabolism. If the magnesium intake is high, the kidney excretes excess magnesium absorbed from the intestine or mobilized from bone. When the magnesium intake is low, negative balance can usually be prevented by almost total renal conservation of the element.

\section{Renal handling of magnesium is determined by} glomerular filtration, resorption and eventually by secretion. Unlike monovalent ions, magnesium is not freely filterable. Since approximately $30 \%$ of the magnesium in the plasma is bound to protein, only $70 \%$ of the serum magnesium is filterable. In the ultrafiltrate, as in the serum, magnesium should exist in two physiochemical states: as the free ion and complexed (9). The ligands might be citrate, phosphate, sulfate and various organic acids. These complexes will be small enough to pass the glomerular filter. Data on ionized magnesium in the ultrafiltrate are not available.

Approximately $3.5 \%$ of the filtered magnesium is excreted into the urine. Therefore the rest must be reabsorbed. In micropuncture experiments it was found that in the proximal tubule, magnesium reabsorption is not isotonic, unlike sodium, potassium and calcium reabsorption. In the rat, $T F / P$ values of ultrafiltrated magnesium increase with tubule length. Late proximal $\mathrm{TF} / \mathrm{P}$ values of $1.5-2.0$ are reached $(2,84,85)$. Similarly high TF/P values have been found in Psamommys (86). For dogs, a TF/P value of 1.2 is reported (87). The simultaneously determined $\mathrm{TF} / \mathrm{P}$ inulin values were always higher than that of magnesium and indicate that magnesium is reabsorbed. In the proximal tubule approximately $20-30 \%$ of the filtered magnesium is reabsorbed $(84,85,87)$ in contrast to sodium, potassium and calcium, which are characterized by a. $60 \%$ reabsorption in the proximal tubule.

In the early-distal tubule the recovery of filtered magnesium was $15 \%$ in rats and $8 \%$ in dogs $(85,87)$. Thus it 
could be concluded that the main part of magnesium reabsorption, approximately $55 \%$ in rats and $63 \%$ in dogs, is localized within Henle's loop. Micropuncture of Henle's loop in the region of the papilla showed that the fraction of filtered magnesium there is not different from the late proximal fraction (85). This has been interpreted as evidence that 1) magnesium is not reabsorbed in the descending limb of Henle's loop and 2) the main part of magnesium reabsorption is localized in the ascending limb of Henle's loop.

The distal tubule obviously is not important for magnesium reabsorption in the rat and the dog. Late-distal and in the collecting duct there is no further magnesium reabsorption $(85,87,88)$.

Tubular magnesium reabsorption is charaterized by a limited capacity. In the rat, magnesium reabsorption is near to saturation at physiological magnesium concentrations in serum (89). In the dog, maximal magnesium transport capacity is reached in the range of pathologically increased serum magnesium values. The $\mathrm{Tm}$ value was $140 \mu \mathrm{g} / \mathrm{min} \cdot \mathrm{kg}$ body weight $(90,91)$.

The question of whether mammals resemble aglomerular fish in being able to secrete magnesium during antidiuresis is a matter of controversy at the moment. So far, magnesium secretion has been produced in rats or dogs only under the condition of an acute or chronic hypermagnesemia or during a massive diuresis $(92$, 93). Other authors did not succeed in producing a magnesium secretion under these conditions (94). A possible site for magnesium secretion is the descending limb of Henle's loop. This was concluded from the following findings: 1) micropuncture of the loop of Henle at the papilla yielded $131 \%$ of the filtered magnesium; 2) compared to control animals, the percent magnesium reabsorption of the late proximal tubule was unchanged (93). It is an open question whether magnesium secretion also takes place at normal magnesium serum values. In the descending limb of Henle's loop, no net magnesium reabsorption could be demonstrated under these conditions. In this case magnesium secretion should be counterbalanced by magnesium reabsorption of the same magnitude.

Tubular magnesium reabsorption is affected by several factors. Expansion of the extracellular fluid by infusion of sodium chloride results in increased magnesium excretion produced by an inhibition of tubular magnesium reabsorption $(95,96)$. Renal vasodilation produced by intraarterial injection of acetylcholine or bradykinin increases the excretion of sodium, calcium and magnesium (97-99). Acute administration of alcohol is followed by an increased urinary excretion of magnesium, both in normal men and in alcoholics (100). As was shown by conventional clearance techniques in dogs the acute as well as the chronic magnesuric effect of alcohol is caused by an increase of filtered load due to an elevation in GFR while per cent magnesium re- absorption was unchanged (101). Interestingly alcoholics are frequently magnesium deprived. Balance studies with normomagnesemic nonalcoholics with a daily intake of 11 alcohol over a period of 18 days showed that a negative magnesium balance developed due to a small but significantly increased urinary magnesium excretion and a decreased intestinal $\mathrm{Mg}$ absorption (103). However, after some magnesium depletion, it appears that alcohol has no further magnesiuric effect (103).

Ingestion or infusion of glucose inhibits tubular reabsorption of magnesium $(104,105)$. The mechanism remains obscure. The effect of insulin and other hormones on renal magnesium excretion is described below.

Diuretics affect urinary magnesium excretion. Furosemide, ethacrynic acid and mercurials all produce not only a significant natriuresis, but also a magnesuria (106-110). It is assumed that they inhibit magnesium transport in the ascending limb of Henle's loop. In osmotic diuresis, too, there is an increased magnesium excretion (109). Acetazolamide (106) and thiazides $(107,110,111)$ have no effect on magnesium excretion or at most a small one.

The mechanism of renal magnesium transport, like that of the intestinal transport, is a matter of speculation. Data are required on the concentration of ionized magnesium determined by micropuncture in tubular fluid and serum. Furthermore, data on intracellular magnesium ion concentrations in the various tubule segments are also needed.

\section{Hormonal regulation of magnesium metabolism}

\section{Parathy rin}

As far as we know, parathyrin is the most important hormone in the regulation of magnesium metabolism. However, in contrast to calcium, its effect on magnesium metabolism is less clear, and has been the subject of controversy (9).

In chronic parathyroidectomized rats, the serum concentration of magnesium is decreased (112-114). In balance studies on chronic parathyroidectomized rats, it was found that intestinal uptake of magnesium and urinary losses were increased. It was concluded that parathyrin inhibits, directly or indirectly, intestinal magnesium absorption and facilitates renal magnesium transport. In the same study it was shown that the effects were dependent on calcium intake. A high calcium intake decreased intestinal magnesium absorption and increased renal magnesium excretion $(114,115)$. This may be explained, at least in part, by the findings that calcium per se is known to inhibit intestinal (73) and renal magnesium transport (116). A further explanation for the intestinal effect of parathyrin may be that the hormone promotes renal synthesis of the active form of vitamin $D$, 
which specifically increases intestinal calcium absorption, so that magnesium reabsorption might be hindered. As to the renal action of parathyrin, it was found to stimulate renal magnesium reabsorption in parathyroidectomized rats $(91,117)$ or in intact dogs. As to the intestinal effect of parathyrin and vitamin $D$, it should be mentioned that contradictory results, i.e. an increase in magnesium absorption, have been reported by other authors (118-120).

In humans a renal effect of parathyrin was demonstrated in patients with hypoparathyroidism. In these patients, the urinary magnesium excretion was reduced by repeated injection of parathyroid extracts (121). In balance studies it was shown that in patients with primary hyperparathyroidism serum magnesium is usually unchanged and the magnesium balance remains positive. Only in more severe cases is the serum magnesium lowered so that the magnesium balance becomes negative. These patients are characterized by a paradoxical increase in renal magnesium excretion $(118,122,123)$. This may be explained by increased bone mobilization by parathyrin which leads to hypercalcemia; this, in turn, counteracts a parathyrin mediated increase in magnesium reabsorption. After partial parathyroidectomy, the increased renal losses of magnesium are reduced to the normal range and the magnesium balance becomes positive.

If magnesium metabolism were regulated directly by the parathyroid gland, there could be a relation between serum magnesium and secretion of parathyrin, as has been established for calcium. In vivo experiments in goats with parathyroid glands perfused in situ demonstrated an inhibition of parathyrin secretion with increasing magnesium (124). More detailed studies in vitro with bovine parathyroid slices showed that increasing calcium or magnesium concentrations inhibited the secretion of immunoreactive parathyrin. On a molar basis, the potency of calcium was 2.5 times better than that of magnesium.

Since in short term experiments the ions did not affect the conversion of proparathyrin to parathyrin, it is assumed that they inhibit the release rather than the synthesis of parathyrin (125). In cell suspensions and cell cultures of bovine parathyroid, physiological concentrations of calcium and magnesium depressed the release of parathyrin and of the concomittant secretory protein. Vice versa, lowering the calcium or magnesium concentration in the medium increased parathyrin secretion. In this model, there was no quantitative difference in the inhibitory action of calcium and magnesium (126-128). Interestingly, the inhibitory effect of one of these cations was increased by the presence of a minimal concentration of the other cation. This interdependence of calcium and magnesium was taken as evidence that both ions react with different membrane receptors. Both receptors must be occupied before secretion of parathyrin can be effectively controlled (128).

However, in patients with primary hypomagnesemia with secondary hypocalcemia, the stimulatory effect of low magnesium concentration on parathyrin secretion is not present. In these patients the serum concentration of immunoreactive parathyrin is normal or decreased. After intravenous infusion of magnesium, but not of calcium, the secretion rate of parāthyrin is paradoxically increased (129-132).

\section{Vitamin D}

Not many data on the interaction of vitamin $\mathrm{D}$ with magnesium metabolism are available. In the older literature it was reported that serum magnesium is decreased by the administration of vitamin $\mathrm{D}(133-135)$, while intestinal absorption of the ions is unchanged (74) or even stimulated $(133,136)$. In the intact and parathyroidectomized rat, renal magnesium excretion was decreased by vitamin $\mathrm{D}$ and the magnesium balance was positive $(135,137)$. In patients with chronic renal failure, long term administration of the synthetic vitamin $\mathrm{D}$ analogue 1-hydroxy-cholecalciferol had no effect on intestinal magnesium uptake or serum magnesium, while the lowered serum calcium was normalized $(138,139)$. In very recent studies in humans a smäll increase in intestinal absorption and urinary excretion of $\mathrm{Mg}$ by vitamin D (25-hydroxy-; 1,25-dihydroxy; 1-hydroxycholecalciferol) with no change in Mg balance was found (139a). On the other hand no correlation of net intestinal $\mathrm{Mg}$ absorption with plasma 1,25-dihydroxy-cholecalciferol concentration was found (139b). Probably, other factors may play a role in the regulation of intestinal $\mathrm{Mg}$ absorption in humans.

\section{Calcitonin}

In mammals phy siological doses of calcitonin have no effect on magnesium metabolism. In rats pharmacological doses of calcitonin lower serum magnesium $(140,141)$. Other authors reported a decreased urinäry excretion of the ion in rats (142-144). In humans in contrast to rats pharmacological doses of calcitonin produced a transient magnesuria $(145,146)$. Since magnesuria is paralleled by an enhanced natriuresis, which by itself produces a magnesuria, the effect of calcitonin on renal magnesium excretion may be unspecific. Whether the reported different effect of calcitonin in rats and humans is due to species differences remains to be clarified.

\section{Mineralocorticoids}

The effects of adrenal steroids on magnesium have only been reported in the older literature. After adrenalectomy, serum and tissue magnesium are increased $(113,146-148)$. Acute administration of aldosterone had no effect on urinary magnesium excretion of 
adrenalectomized dogs (149). However, in several species, long-term administration of aldosterone increased renal magnesium excretion $(150,151)$ and normalized serum as well as tissue magnesium levels $(113,148)$. The longterm effect of mineralocorticoids on magnesium may be not a direct one, and has been explained as a consequence of extracellular volume expansion by the sodium retained (152). As already mentioned, extracellular volume expansion inhibits tubular magnesium reabsorption $(95,96)$. This also explains why acute administration of mineralocorticoids has no effect on renal magnesium excretion in the dog (149). In acute experiments, glucocorticoids have no influence on renal magnesium excretion of adrenalectomized dogs (149).

As could be expected from animal experiments, patients with primary aldosteronism show an increased renal excretion of magnesium. Also, aldosterone increases urinary magnesium excretion when given to adrenalectomized patients. The aldosterone effect could be counteracted by spironolactone (153). In normal subjects the acute infusion of aldosterone or cortisol produced no change in the magnesium clearance (154).

\section{Thyroid hormone}

Magnesium metabolism is also influenced by thyroid hormone. In thyrotoxic rats, serum and skeletal muscle magnesium are increased. Conversely, hypothyroid rats treated with propylthiouracil had lower levels of serum and muscle magnesium $(113,148,155)$.

In contrast to rats, low serum levels and increased renal losses of magnesium have been found in hyperthyroid patients, while in hypothyroidism, serum magnesium was increased and urinary magnesium excretion was reduced $(156,157)$. It cannot be said whether the differences in the results obtained in rats and in humans are solely due to species differences, or caused by the difference in pathogenesis of human and experimentally induced disease.

\section{Insulin}

In rats with an alloxan-or strèptożotocin-induced diabetes mellitus, duodenal reabsorption of calcium and magnesium are reduced. At the same time, renal mag: nesium excretion is increased. The renal magnesium wasting results in a hypomagnesemia and a negative magnesium balance $(158-160)$. The reduced intestinal magnesium uptake may be a consequence of the secondary hyperparatthyroidism that is frequently observed in diabetic rats (158). The increased renal excretion of magnesium might be caused by the osmotic diuresis maintained by a glucosuria, which counteracts the promoting effect of parathyrin on tubular magnesium reabsorption.

Like the rats, diabetic patients suffer from lowered serum magnesium and increased urinary loss of the ion $(161,162)$. In a routine investigation on 5100 patients it was found that hypomagnesemia was most frequently associated with diabetes mellitus (7).

\section{Adrenalin}

Injection of a high dose of adrenalin caused hypermagnesemia in rats and ewes by a loss of intracellular magnesium. Infusion of adrenalin at a dose of $40 \mu \mathrm{g} \cdot \mathrm{kg}^{-1} \cdot \mathrm{h}^{-1}$ into sheep caused hypomagnesemia (163).

\section{Hypomagnesemia}

At low magnesium intake the kidney almost completely reabsorbs magnesium. Thus, in adults small variations of dietary magnesium intake usually do not produce a hypomagnesemia. Only an extreme reduction of the magnesium intake as is the case in fasting, or iatrogenic by long term infusion of magnesium free solutions can hypomagnesemia be produced. More commonly, hypomagnesemia is observed as a result of reduced intestinal uptake or decreased tubular reabsorption. Reasons for a decreased intestinal uptake of magnesium are: removal of the small intestine, chronic diarrhoea, various malabsorption syndromes. Increased renal losses of magnesium with a resulting hypomagnesemia have been observed under the following conditions: after long term therapy with diuretics, in the polyuria phase of acute renal failure, in chronic alcoholism, and in diabetic patients.

A rare cause of hypomagnesemia is a defect in intestinal absorption (164-166) or renal tubular reabsorption (167-169) of magnesium as a familial disorder. The mechanism of these defects is obscure. Symptoms indicating hypomagnesemia may be: increased neuromuscular excitability, carpopedal spasms, tetany. However, since hypomagnesemia in most cases does not occur as an isolated symptom, but usually is associated with hypocalcemia and hypokalemia, the specificity of these symptoms is an open question. For a more detailed review on hypomagnesemia in patients see 1.c. (9, 170-172).

The diagnosis of magnesium deficiency is not easy. When magnesium intake is reduced or renal magnesium losses are increased, the serum level of magnesium should be lowered. However, this is not necessarily the case, since the ionized part of serum magnesium representing only $1 \%$ of total body magnesium is in equilibrium with magnesium bound to bone, which contains approximately $50 \%$ of total body magnesium. Under these conditions, magnesium is released from the bone so that the lowered serum level is counterbalanced and may be changed only within the limits of normal range. For practical reasons, therefore, a magnesium deficit is usually assumed that in hypomagnesemia. Indeed, a 
positive correlation of serum and bone magnesium has been established in patients. However, in contrast to bone, muscle magnesium seems to change independently of serum magnesium (173). Furthermore, in uremic patients with chronic renal failure, serum magnesium has been found to be normal or mostly elevated, whereas the bone magnesium content was considerably diminished (174). Thus serum magnesium is not always a reliable indicator of magnesium deficiency. Perhaps the measurement of renal excretion of an intravenous magnesium load would provide an additional aid in the diagnosis of magnesium deficiency, provided that

1) circulation and renal function are normal and

2) water metabolism is in balance.

Multiple factors are involved in the mechanism of secondary hypocalcemia in hypomagnesemia. One main reason is the skeletal resistance to the calcemic action of parathyrin. In patients with hypomagnesemia, several authors could not restore the lowered values of serum calcium by administration of parathyroid extract (175-177). However, administration of magnesium alone normalized the responsiveness to parathyroid extract in these patients. It should be mentioned that some authors failed to detect a skeletal resistance to parathyrin in hypomagnesemia patients (178). Also in animals such as the chicken (179) and the dog (180) magnesium depletion is associated with hypocalcemia that is less responsive to parathyroid extract and was normalized by magnesium repletion. It should be noted that in the magnesium depleted rat, hypo-, normoor hypercalcemia is observed, dependent on the calcium content of the magnesium deficient diet (181). However, the skeletal resistance to parathyroid hormone was also present in these animals (182).

A second reason for hypocalcemia as a consequence of hypomagnesemia is an impaired function of the parathyroid gland. Blood levels of parathyrin were not elevated as is to be expected in hypocalcemia but were depressed or even undetectable under these conditions $(129,130,183)$. After administration of magnesium, blood levels of parathyrin increased markedly (131, 132).

In contrast to humans, an isolated hypomagnesemia can be produced in young rats by a magnesium-deficient diet. After one week the first visible symptoms, the formation of multiple edema and of ery thema, can be observed. Later, growth is retarded, tetany and paresis develop, the circulating immunoglobulins are diminished, the skin develops trophic lesions, calcemic precipitates are formed in several organs such as kidney, heart, and aorta, and occasionally a thymoma develops. In these animals the hypornagnesemia is paralleled by a small but significant reduction of intracellular magnesium. Thus, at least in growing animals, hypomagnesemia indicates magnesium depletion (184).
When intracellular magnesium decreases during growth under the conditions of magnesium deprivation, one can expect dissociation of magnesium-RNA complexes. In $E$. coli, the ribosomes disintegrate and growth is retarded. Because of the defective growth, intracellular magnesium is not further decreased. In addition, buffering of intracellular magnesium maintains intracellular magnesium at a relatively constant level.

Magnesium depletion also affects sodium and potassium metabolism. $\mathrm{Mg}$ deficient animals are characterized by a rise of sodium and a fall of potassium in the muscle (185-187) and heart $(184,187)$. Since the width of the zona glomerulosa of the adrenal cortex (188) and the secretion of aldosterone (189) were found to increase, in magnesium depleted rats, the changes in cellular electrolyte contents were explained by hyperaldosteronism (189). However, it is well known that aldosterone enhances $\mathrm{Na}^{+}$transport out of the cell and $\mathrm{K}^{+}$uptake into the cell. Therefore, in $\mathrm{Mg}$ deficient rats, the antagonistic effects of hyperaldosteronism and hypocorticism (also found in Mg deficiency (189)) may be present.

The decrease of cellular potassium and increase of sodium and calcium are also present in Yoshida ascites tumor cells (190) and fibroblasts (191) grown in vitro in magnesium deficient media without any addition of aldosterone. In this model the changed intracellular electrolyte concentrations have been explained by a change in cellular permeability. In these cells the potassium efflux was increased much more than potassium influx (190). As a consequence of increased intracellular sodium levels, the distribution of intracellular calcium is changed. It is known that under these conditions heart and muscle mitochondria exchange caicium against sodium (192).

The increase in cytosolic calcium is followed by an increase in potassium permeability, at least in liver and ery throcytes $(193,194)$. Adenylate cyclase is activated by an increase of cytosolic calcium up to $10^{-4} \mathrm{~mol} / \mathrm{l}$, as shown for synaptosomes in vitro (195). For the mechanism see (196-198). Indeed, in Yoshida ascites tumor cells grown in magnesium-deficient media, and in several organs (heart, liver, adipose tissue) of magnesium deprived young rats, cellular cAMP was increased $(199,200)$. With the model of the isolated perfused liver it has been shown that an increase in cellular cAMP may cause a further increase in potassium and calcium permeability (201). Swelling and disruption of the cells finally is prevented by an activation of $\left(\mathrm{Na}^{+}+\mathrm{K}^{+}\right)$-ATPase due to the increase in intracellular sodium, so that the higher leak fluxes are counterbalanced by an increase in active transport of sodium and potassium $(190,202)$.

In magnesium-deprived cells the rates of DNA, RNA and protein biosynthesis are impaired $(190,191)$. The same effect is produced in Yoshida ascites tumor cells by the ionophor X 537 A (203). Intracellular sodium, calcium and cAMP are also increased, but potassium is decreased in X 537 A-treated cells, as in magnesium deficiency. 
From this it is concluded that the inhibition of DNA, RNA and protein synthesis observed in magnesium deprivation are primarily caused by the changes in intracellular electrolyte concentrations. Secondarily, an alteration in intracellular enzymes involved in protein synthesis may occur. A reduced activity of elongation factor 1 and 2 was found in lymphocytes from magnesium deficient rats (204). This may be a reason why the effects of $\mathrm{Mg}$-deficiency were only normalized by $\mathrm{Mg}$ in conjunction with protein synthesis $(24,190)$. In the animal, several additional changes are superimposed on these cellular events. Since in hypomagnesemia the competition of magnesium with calcium is impaired, more calcium permeates. Therefore calcium-dependent reactions such as the release of catecholamines (205) are activated. In magnesium-deprived rats an increased release and urinary excretion of catecholamines is found (206). Since catecholamines are known to activate adenylate cyclase and to increase CAMP, the cellular biochemical reactions of magnesium deficiency may be enhanced by catecholamines. However, it is an open question whether the described components of the reaction mechanism in magnesium deficiency are expressed to the same degree in all cells and organs, since they differ in cation permeability and adenylate cyclase activity, and are characterized by a different sensitivity to catecholamines.

\section{Hypermagnesemia}

After an acute oral or intravenous magnesium load, the ion is excreted in the urine within 24-48 hours (106, 207). Therefore one can expect hypermagnesemia when kidney function is considerably impaired and renal Tm $\mathrm{Mg}$ is reached. Accordingly; acute and chronic renal failure are the most common reasons for hypermagnesemia. Hypermagnesemia can also be produced by a massive magnesium overload, e.g. in the newborn after magnesium therapy of the mother because of eclampsia during parturition. The symptoms of hypermagnesemia are related to nerves, muscle and heart. Depending on the degree of magnesium intoxication, the myogenic tonus decreases and muscle paralysis develops. At serum concentrations of $3 \mathrm{mmol} / 1$ deep tendon reflexes dis- appear. At $5 \mathrm{mmol} / \mathrm{l}$ muscle paralysis begins to include respiratory muscles. The heart shows some ECG abnormalities and becomes bradycardic. Also, hypotension develops. A detailed review on excess magnesium has been published very recently (208).

Magnesium intoxication could be caused by an increase in intracellular magnesium and/or by the increased extracellular magnesium. As mentioned in the chapter "magnesium transport", non-growing cells show only a magnesium exchange, but no net uptake of the ion. In $E$. coli the increase in extracellular magnesium is followed by an increased binding of the ion on the extracellular surface of the cell membrane. No substantial change in intracellular magnesium could be detected (53). A small increase in intracellular magnesium has no significance in cellular metabolism, since 1) intracellular magnesium is buffered, 2) the dependence of several enzymes on magnesium is changed with the $\mathrm{pMg}$ in such a way that large changes of the magnesium concentrations are necessary before enzyme activation is changed significantly, 3 ) the intracellular $\mathrm{pMg}$ is at the $\mathrm{pMg}$ optimum of most magnesium-dependent cells (19).

Therefore the symptoms of magnesium intoxication must be primarily due to the increased extracellular magnesium. Presumably several calcium-dependent reactions are inhibited competitively by high magnesium concentration. Muscle paralysis during magnesium intoxication is explained by inhibition of acetylcholine release in the neuromuscular synapse and by a decrease in postsynaptic excitability (208-211). The inhibition of cholinergic transmission of the autonomous system is explained by an analogous mechanism $(210,212)$. Also, transmission in adrenergic synapses is blocked by magnesium. This is caused by inhibition of noradrenalin release and acceleration of the noradrenalin reuptake (213-215). The mechanism by which the PR intervals in the ECG are prolonged so that a complete heart block and sometimes even heart arrest in systole may be observed, are not well understood (208). The hypotension is caused by dilatation of resistance vessels, which has been explained by a decreased excitability of the smooth muscles and an inhibition of electro-mechanical coupling (216, 217).

\section{Refereñuces}

1. Teears, R. J., Barnes, B. A., Batsakis, J. G. \& Bloch, D. M. (1977) Am. J. Clin. Pathol. 68 suppl. 159-161.

2. Morel, F., Roinel, N. \& Le Grimellec, C. (1969) Nephron 6, $350-364$.

3. Vurek, G. G. (1967) Anal. Chem. 39, 1599-1601.

4. Dagnall, R. M., Smith, R. \& West, T. S: (1967) Analyst (London) 92, 20-26.

5. Brunette, M. G. \& Crochet, M. E. (1975) Anal. Biochem. $65,79-88$.

6. Hänze, S. (1964) Der Magnesium-Stöffwechsel. Physiologie und Klinik. Georg Thieme Verlag, Stuttgart.
7. Jackson, C. E. \& Meier, D. W. (1968) Ann. Intern. Med. 69, $743-748$.

8. Seelig, M. S. \& Berger, A. R. (1974) N. Engl. J. Med. 290, 974-975.

9. Walser, M. (1967) Ergebn. Physiol. Biol. Chem. Exp. Pharmakol. 59, 185-341.

10. Iyengar, G. V., Kollmer, W. E. \& Bowen, H. J. M. (1978) The Elemental Composition of Human Tissues and Body Fluids. Verlag Chemie, Weinheim New York.

11. Griswold, R. L. \& Pace, N. (1956) Exp. Cell. Res. 11, 362-367. 
12. Thiers, R. E. \& Vallee, B. L. (1957) J. Biol. Chem. 226, 911-920.

13. George, G. A. \& Heaton, F. W. (1975) Biochem. J. 152, 609-615.

14. Bogucka, K. \& Wojtczak, L. (1971) Biochem. Biophys: Res. Commun. 44, 1330-1337.

15. Bogucka, K. \& Wojtczak, L. (1976) Biochem. Biophys. Res. Commun. 71, 161-167.

16. Brintzinger, H. \& Fallab, S. (1960) Helv. Chim. Acta 43, 43-58.

17. Malmström, G. \& Rosenberg, A. (1959) Adv. Enzymol. Relat. Areas Mol. Biol. 21, 131-167.

18. Cohn, M. (1963) Biochemistry 2, 623-629.

19. Günther, T. (1965) Habilitationsschrift, Freie Universität Berlin.

20. Ahlers, J. \& Günther, T. (1975) Z. Naturforsch. 30c, 412-416.

21. Hendrickson, H. S. \& Fullington, J. G. (1965) Biochemistry 4, 1599-1605.

22. Träuble, H. \& Eibl, H. (1974) Proc. Nat. Acad. Sci. USA $71,214-219$.

23. Günther, T., Richter, L. \& Schmalbeck, J. (1975) J. Gen. Microbiol. 86, 191-193.

24. Günther, T. \& Mariß, P. (1968) Z. Naturforsch. 23b, $334-338$.

25. Pörschke, D. (1979) Nucleic Acids Res. 6, 883-898.

26. Quigley, G. J., Teeter, M. M. \& Rich, A. (1978) Proc. Nat. Acad. Sci. USA 75, 64-68.

27. Goldberg, A. (1966) J. Mol. Biol. 15, 663-673.

28. Stein, A. \& Crothers, D. M. (1976) Biochemistry 15 , $157-160$.

29. Beaudry, P., Begard, E., Douzou, P. \& Grunberg-Manago, M. (1978) Eur. J. Biochem. 92, 613-619.

30. Weller, D. B., Shechter, Y., Musgrave, D., Rougvie, M. \& Horowitz, J. (1968) Biochemistry 7, 3668-3675.

31. McCarthy, B. J. (1962) Biochim. Biophys. Acta 55, 880-888.

32. Nanninga, L. B. (1961) Biochim. Biophys. Acta 54, 338-344.

33. Veloso, D., Guynn, R. W., Oskarsson, M. \& Veech, R. L. (1973) J. Biol. Chem. 248, 4811-4819.

34. Günther, T. (1967) Z. Naturforsch. 22b, 149-154.

35. Günther, T. \& Dorn, F. (1971) Z. Naturforsch. 26b, 176-177.

36. Günther, T. (1966) Z. Naturforsch. 21 b, 1174-1177.

37. Takeda, Y. (1969) Biochim. Biophys. Acta 182, 258-261.

38. Szer, W. \& Ochoa, S. (1964) J. Mol. Biol. 8, 823-834.

39. Davies, J., Gilbert, W. \& Gorini, L. (1964) Proc. Nat. Acad. Sci. USA 51, 883-889.

40. Nishimura, S., Harada, F. \& Hirabayashi, M. (1969) J. Mol. Biol. 40, 173-186.

41. Lucas-Lenard, J. \& Lipmann, F. (1967) Proc. Nat. Acad. Sci. USA 57, 1050-1057.

42. Lucas-Lenard, J. \& Lipmann, F. (1971) Ann. Rev. Biochem. 40, 409-448.

43. Subramanian, A. R., Ron, E. Z. \& Davis, B. D. (1968) Proc. Nat. Acad. Sci. USA 61, 761-767.

44. Rogers, T. A. \& Mahan, P. E. (1956) Proc. Soc. Exp. Biol. Med. 100, 235-239.

45. Rogers, T. A., Haven, F. L. \& Mahan, P. E. (1960) J. Nat. Cancer Inst. 25, 887-888.

46. Aikawa, J. K., Rhoades, E. L., Harms, D. R. \& Reardon, J. Z. (1969) Am. J. Physiol., 197, 99-101.

47. Page, E. \& Polimeni, P. I. (1972) J. Physiol. (London) 224, 121-139.

48. Beauchamp, R. S., Silver, S. \& Hopkins, J. W. (1971) Biochim. Biophys. Acta 225, 71-76.

49. Silver, S. \& Clark, D. (1971) J. Biol. Chem. 246, 569-576.

50. Nelson, D. L. \& Kennedy, E. P. (1971) J. Biol. Chem. 246, 3042-3049.

51. Nelson, D. L. \& Kennedy, E. P. (1972) Proc. Nat. Acad. Sci. USA 69, 1091-1093.

52. Park, M. H., Wong, B. B. \& Lusk, J. E. (1976) J. Bacteriol. 126, 1096-1103.

53. Günther, T. \& Hoffmann, C. F. (1973) Z. Klin. Chem. Klin. Biochem. 11, 237-242.
54. Kung, F.-C., Raymond, J. \& Glaser, D. A. (1976) J. Bacteriol. $126,1089-1095$.

55. Kun, E. (1976) Biochemistry 15, 2328-2336.

56. Johnson, J. H. \& Pressman, B. C. (1969) Aroh. Biochem. Biophysics 132, 139-145.

57. Siliprandi, D., Toninello, A., Zoccarato, F.\& Siliprandi, N. (1977) Biochem. Biophys. Res. Commun. 78, 23-27.

58. Bygrave, F. L. (1978) Biol. Rev. 53, 43-79.

59. Carvalho, A. P. \& Leo, B. (1976) J. Gen. Phy siol. 50, $1.327-1352$.

60. Kanazawa, T. \& Boyer, P. D. (1973) J. Biol. Chem. 248 , 3163-3172.

61. Urban, E. \& Sched1, H. P. (1969) Proc. Soc. Exp. Biol. Med. $132,1110-1113$.

62. Behar, J. (1974) Am. J. Physiol. 227, 334-340.

63. Brannan, P. G., Vergne-Marini, P., Pak, C. Y. C., Hull, A. R. \& Fordtran, J. S. (1976) J. Clin. Invest. 57, 1412-1418.

64. Ross, D. B. (1962) J. Physiol. (London) 160, 417-428.

65. O'Donnell, J. M. \& Smith, M. W. (1973) J. Physiol. (London) 229, 733-749.

66. Care, A. D. \& van't Klooster, A. T. (1965) J. Physiol. (London) 177, 174-191.

67. Tidball, C. S. (1964) Am. J. Physiol. 206, 243-246.

68. DiBona, G. F. (1972) Am. J. Physiol. 223, 1324-1326.

69. Barry, R. J. C. \& Eggenton, J. (1972) J. Phy siol. (London) 227, 201-216.

70. Scott, D. (1965) Quart. J. Exp. Physiol. 50, 312-329.

71. Cassidy, M. M. \& Tidball, C. S. (1969) Am. J. Physiol. 217, 674-679.

72. Martens, H., Harmeyer, J. \& Michael, H. (1978) Res. Vet. Sci. 24, 161-168.

73. Behar, J. (1975) Am. J. Physiol. 229, 1590-1595.

74. Heaton, F. W., Hodgkinson, A. \& Rose, G. A. (1964) Clin. Sci. 27, 31-40.

75. Bunce, G. E., Sauberlich, H. E., Reeves, P. G. \& Oba, T. S. (1965) J. Nutr. 86, 406-414.

76. Hanna, S., Harrison, M., MacIntyre, I. \& Fraser, R. (1960) Lancet $I I, 172-175$.

77. Balint, J. A. \& Hirschowitz, B. J. (1961) New Engl. J. Med. $265,631-633$.

78. MacIntyre, I., Hanna, S., Booth, C. C. \& Read, A. E. (1961) Clin. Sci. 20, 297-305.

79. Booth, C. C., Babouris, N., Hanna, S. \& MacIntyre, I. (1963) Brit. Med. J. 2, 141-144.

80. Opie, L. H., Hunt, B. G. \& Finlay, I. M. (1964) Gastroenterology 47, 415-420.

81. Tadayyon, B. \& Lutwak, L. (1969) J. Nutr. 97, 246-254.

82. Widdowson, E. M. (1965) Lancet $I I, 1099-1105$.

83. Tantibhedhyangkul, P. \& Hashim, S. A. (1978) Pediatrics, $61,537-545$.

84. LeGrimellec, C., Roinel, N. \& Morel, F. (1973) Pflügers Arch. 340, 181-196.

85. Brunette, M. G., Vigneault, N. \& Carriere, S. (1974) Am. J. Physiol. 227, 891-896.

86. de Rouffignac, C., Morel, F., Moss, N. \& Roinel, M. (1973) Pflügers Arch. 344, 309-326.

87. Quamme, G. A., Wong, N. L. M., Dirks, J. H., Roinel, N., de Rouffignac, C. \& Morel, F. (1978) Pflügers Arch. 377, 95-99.

88. Brunette, M. G., Vigneault, N. \& Carriere, S. (1978) Pflügers. Arch. 373, 229-235.

89. Averill, C. M. \& Heatọ, F. W. (1966) Clin. Sci. 31, 353-360.

90. Knippers, R. \& Hehl, U. (1965) Z. Gesamte Exp. Med. 139, 154-165.

91. Massry, S. G., Coburn, J. W. \& Kleeman, C. R. (1969) Am. J. Physiol. 216, 1460-1467.

92. Wen, S. F., Wong, N. L. M. \& Dirks, J. H. (1971) Am. J. Physiol. 220, 33-37.

93. Brunette, M. G., Vigneault, N. \& Carriere, S. (1975) Am. J. Physiol. 229, 1695-1701.

94. Alfredson, K. S. \& Walser, M. (1970) Nephron, 7, 241-247.

95. Brunette, M., Wen, S. F., Evanson; R.-L. \& Dirks, J. H. (1969) Am. J. Physiol. 216, 15.10-1516.

96. Massry, S. G., Coburn, J. W., Chapman, L. W. \& Kleeman, C. R. (1967) Am. J. Physiol. 213, 1218-1224". 
97. Gonda, A., Wong, N., Seely, J. F. \& Dirks, J. H. (1969) Can. J. Physiol. Pharmacol. 47, 619-626.

98. Ahumada, J. J. \& Massry, S. G. (1971) Clin Sci. 41, 109-121.

99. Thompson, R. B., Kaufman, C. E. \& DiScala, V. A. (1971) Am. J. Physiol. 221, 1097-1104.

100. Kalbfleisch, J. M., Lindeman, R. D., Ginn, H. E. \& Smith, W. O. (1963) J. Clin. Invest. 42, 1471-1475.

101. Sargent, W. Q., Simpson, J. R. \& Beard, I. D. (1974) J. Pharmacol. Exp. Therap. 190, 507-514.

102. McDonald, J. T. \& Margen, S. (1979) Am. J. Clin. Nutr. $32,823-833$.

103. Dunn, M. J. \& Walser, M. (1966) Metabolism 15, 884-895.

104. Lindeman, R. D., Adler, S., Yiengst, M. J. \& Beard, E. S. (1967) J. Lab. Clin. Med. 70, 236-246.

105. Lennon, E. J., Lemann jr. J., Piering, W. F. \& Larson, L. S. (1974) J. Clin. Invest. 53, 1424-1433.

106. Barker, E. S., Elkinton, J. R. \& Clark, J. K. (1959) J. Clin. Invest. 38, 1733-1745.

107. Demartini, F. E., Briscoe, A. M. \& Ragan, C. (1967) Proc. Soc. Exp. Biol. Med. 124, 320-324.

108. Duarte, C. G. (1968) Metabolism, 17, 867-876.

109. Parfitt, A. M. (1969) Clin. Sci. 36, 267-282.

110. Eknoyan, G., Suki, W. N. \& Martinez-Maldonado, M. (1970) J. Lab. Clin. Med. 76, 257-266.

111. Parfitt, A. M. (1972) J. Clin. Invest. 51, 1879-1888.

112. Heaton, F. W. (1965) Clin. Sci. 28, 543-553.

113. Günther, T. \& Alter, C. (1967) Z. Klin. Chem. Klin. Biochem. 5, 67-72.

114. Clark, I. \& Rivera-Cordero, F. (1974) Endocrinology, 95 , 360-369.

115. Clark, I. \& Rivera-Cordero, F. (1973) Endocrinology, 92, 62-71.

116. Coburn, J. W., Massry, S. G. \& Kleeman, C. R. (1970) Nephron 7, 131-141.

117. MacIntyre, I., Boss, S. \& Throughton, V. A. (1963) Nature $198,1058-1060$.

118. Hanna, S., North, K. A. K., Macintyre, I. \& Fraser, R. (1961) Brit. Med. J., 2, 1253-1256.

119. MacIntyre, I. \& Robinson, C. J. (1969) Ann. N. Y. Acad. Sci. 162, 865-873.

120. Seelig, M. S. (1964) J. Clin. Nutr. 14, 342-390.

121. Bethune, J. E., Turpui, R. A. \& Inone, H. (1968) J. Clin. Endocrinol. Metab. 28,673-678.

122. Heaton, F. W. \& Pyrah, L. N. (1963) Clin. Sci. 25, 475-485.

123. King, R. G. \& Stanbury, S. W. (1970) Clin. Sci. 39, 281-303

124. Buckle, R. M., Care, A. D., Cooper, C. W. \& Gitelman, H. J. (1968) J. Endocrinol. 42, 529-534.

125. Habener, J. F. \& Pottts jr., J. T. (1976) Endocrinology 98, 197-202.

126. Targovniki, J. H., Rodman, J. S. \& Sherwood, L. M. (1971) Endocrinology 88, 1477-1482.

127. Brown, E. M., Hurwitz, S. \& Aurbach, G. D. (1976) Endocrinology 99, 1582-1588.

128. Morrissey, J. J. \& Cohn, D. V. (1978) Endo crinology 103 , 2081-2090.

129. Anast, C. S., Mohs, J. M., Kaplan, S. L. \& Burns, T. W. (1972) Science 177, 606-608.

130. Suh, S. M., Tashjian jr., A. H., Matsuo, N., Parkinson, D. K. \& Fràser, D. (1973) J. Clin. Invest. 52, 153-160.

131. Anast, C. S., Winnacker, J. L., Forte, L. R. \& Burns, T. W. (1976) J. Clin. Endocrinol. Metab. 42, 707-717.

132. Rude, R. K., Oldham, S. B., Sharp jr, C. F. \& Singer, F. R. (1978) J. Clin. Endocrinol. Metab. 47, 800-806.

133. Hanna, S. (1961) Metabolism 10, 735-743.

134. Harrison, H. E. \& Härison, H. C. (1964) Metabolism 13, 952-958.

135. Lifshitz, F., Harrison, H. C. \& Harrison, H. E. (1967) Endocrinology 81, 849-853.

136. Miller, E. R., Ullrey, D. E., Zutaut, D. L., Hoefer, J. A. \& Luecke, R. K. (1965) J. Nutr. 85, 255-259.

137. Clark, I. \& Rivera-Cordero, F. (1971) Endocrinology 88, $302-308$

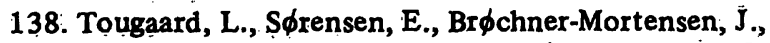
Christensen, M. S., R $\phi$ dbro, P. \& S $\phi$ rensen, A. W. S. (1976) Lancet $I, 1044-1047$. 139a. Hodgkinson, A., Marshall, D. H. \& Nordin, B. E. C. (1979) Clin. Sci. 57, 121-123.

139b. Wilz, D. R., Gray, R. W., Dominguez, J. H. \& Lemann jr., J. (1979) Am. J. Clin. Nutr. 32, 2052-2060.

139. Kanis, J. A., Smith, R., Walton, R. J. \& Bartlett, M. (1977) Brit. Med. J. 1, 211.

140. Palmieri, G. M. A., Thompson, J. S. \& Eliel, L. P. (1969) Endocrinology 84, 1509-1511.

141. Garel, J. M. \& Barlet, J. P. (1974) J. Endocrinol. 61, 1-13.

142. Rasmussen, H., Anast, C. \& Arnaud, C. (1967) J. Clin. Invest. 46, 746-752.

143. Aldred, J. P., Kleszynski, R. R. \& Bastian, J. W. (1970) Proc. Soc. Exp. Biol. Med. 134, 1175-1180.

144. Williams, C. C., Matthews, E. W., Moseley, J. M. \& MacIntyre, I: (1972) Clin. Sci. 42, 129-137.

145. Singer, F. R., Woodhouse, N. J. Y., Parkinson, D. K. \& Joplin, G. F. (1969) Clin. Sci. 37, 181-190.

146. Paillard, F., Ardaillou, R., Malendin, H., Fillastre, J. P. \& Prier, S. (1972) J. Lab. Clin. Med. 80, 200-216.

147. Conway, E. J. \& Hingerty, D. (1946) Biochem. J. 40, $561-568$.

148. Ebel, H., Wolff, J. R., Dorn, F. \& Günther, T. (1971) Z. Klin. Chem. Klin. Biochem. 9, 249-256.

149. Massry, S. G., Coburn, J. W., Chapman, L. W. \& Kleeman, C. R. (1967) J. Lab. Clin. Med. 70, 563-570.

150. Hanna, S. \& MacIntyre, I. (1960) Lancet II, 348-350.

151. Scott, D. \& Dobson, A. (1965) Q. J. Exp. Physiol. 50 , 42-56.

152. Massry, S. G., Coburn, J. W., Chapman, L. W. \& Kleeman, C. R. (1968) J. Lab. Clin. Med. 71, 212-219.

153. Horton, R. \& Biglieri, E. G. (1962) J. Clin. Endocrinol. Metabol. 22, 1187-1192.

154. Lemann jr. J., Piering, W. F. \& Lennon, E. J. (1970) Nephron 7, 117-130.

155. Humphrey, H. P. \& Heaton, F. W. (1972) J. Endocrinol. 53,113-123.

156. Rizek, J. E., Dimich, A. \& Wallach, S. (1965) J. Clin. Endocrinol. 25, 350-358.

157. Jones, J. E., Desper, P. C., Shane, S. R. \& Flink, E. B. (1966) J. Clin. Invest. 45, 891-900.

158. Schneider, L. E. \& Schedl, H. P. (1974) Proc. Soc. Exp. Biol. Med. 147, 494-497.

159. Miller, D. L. \& Schedl, H. P. (1976) Am. J. Physiol. 231, 1039-1042.

160. Fort, P., Lifshitz, F., Wapnir, I. L. \& Wapnir, R. A. (1977) Diabetes 26, 882-886.

161. Stutzman, F. L. \& Amatuzio, D. S. (1953) J. Lab. Clin. Med. 41, 215-219.

162. Butler, A. M. (1950) N. Engl. J. Med. 243, 648-659.

163. Rayssiguier, Y. (1977) Horm. Metabol. Res. 9, 309-314.

164. Paunier, L., Radde, I. C., Kooh, S. W., Conen, P. E. \& Fraser, D. (1968) Pediatrics 41, 385-402

165. Skyberg, D., Strömme, J. H., Nesbakken, R. \& Harnaes (1968) Scand. J. Clin. Lab. Invest. 21, 355-363.

166. Strömme, J. H., Nesbakken, R., Normann, T., Skjörten, F., Skyberg, D. \& Johannessen, B. (1969) Acta Paediat. Scand. $58,433-444$.

167. Giteliman, H. J., Graham, J. B. \& Welt, L. G. (1969) Ann. N.Y. Acad. Sci. 162, 856-864.

168. Booth, B. E. \& Johanson, A. (1974) J. Pediatr. 84, 350-354

169. Paunier, L. \& Sizonenko, P. C. (1976) J. Pediatr. 88, 51-55.

170. Durlach, J. (ed.) 1. Internationales Symposium über den Magnesiummangel in der menschlichen Pathologie, Vittel 1971.

171. Gitelman, H. J. \& Welt, L. G. (1969) Ann. Rev. Med. 20, 233-242.

172. Massry, S. G. (1978) The Clinical pathophysiology of magnesium, in: Contributions to Nephrology (Ritz, E. \& Massry, S. G., Heidland, A. \& Schaefer, K. eds.) Vol. 14, p. 64-73. S. Karger.

173. Alfrey, A. C., Miller, N. L. \& Butkus, D. (1974) J. Lab. Clin. Med. 84, 153-162.

174. Lim, P. \& Jacob, E. (1972) Nephron 9, 300-307.

175. Estep, H., Shaw, W. A., Watlington, C., Hobe, R., Holland, W. \& Tucker, S. G. (1969) J. Clin. Endocrinol. 29, 842-848. 
176. Muldowney, F. P., McKenno, T. J., Kyle, L. H., Freaney, R. \& Swan, M. (1970) N. Engl. J. Med. 282, 61-68.

177. Woodward, J. C., Webster, P. D. \& Carr, A. A. (1972) Digest. Dis. 17, 612-618.

178. Massry, S. G. (1977) Ann. Rev. Pharmacol. Toxicol. 17, 67-82.

179. Reddy, C. R., Coburn, J. W., Hartenbower, D. L., Friedler, R. M., Brickman, A. S., Massry, S. G. \& Jowsey, J. (1973) J. Clin. Invest. 52, 3000-3010.

180. Levi, J., Massry, S. G., Coburn, J. W., Llach, F. \& Kleeman, C. R. (1974) Metabolism 23, 323-335.

181. MacManus, J. \& Heaton, F. W. (1969) Clin. Sci. 36, 297-306.

182. MacManus, J., Heaton, F. W. \& Lucas, P. W. (1971) J: Endocrinol. 49, 253-258.

183. Chase, L. R. \& Slatopolsky, E. (1974) J. Clin. Endocrinol. Metab. 38, 363-371.

184. Martindale, L. \& Heaton, F. W. (1964) Biochem. J. 92, 119-126.

185. MacIntyre, I. \& Davidson, D. (1958) Biochem. J. 70, 456-462.

186. Whang, R., Morosi, H. J., Rodgers, D. \& Reyes, R. (1967) J. Lab. Clin. Med. 70, 895-902.

187. Günther, T. (1970) Z. Klin. Chem. Klin. Biochem. 8, 65-68.

188. Cantin, M. (1970) Lab. Invest. 22, 558-568.

189. Ginn, H. E., Cade, R., McCallum, T. \& Fregley, M. (1967) Endocrinology 80,969-971.

190. Günther, T. \& Averdunk, R. (1970) Z. Klin. Chem. Klin. Biochem. 8, 621-625.

191. Sanui, H. \& Rubin, H. (1977) J. Cell. Physiol. 92, 23-32.

192. Crompton, M., Capano, M. \& Carafoli, E. (1976) Eur. J. Biochem. 69, 453-462.

193. van Rossum, G. D. V. (1970) Nature 225, 638-639.

194. Porzig, H. (1977) J. Membr. Biol. 31, 317-349.

195. Bradham, L. S., Holt, D. A. \& Sims, M. (1970) Biochim. Biophys. Acta 201, 250-260.

196. Cheung, W. Y., Bradham, L. S., Lynch, T. J., Lin, Y. M. \& Tallant, E. A. (1975) Biochem. Biophys. Res. Commun. $66,1055-1062$.
197. Kakiuchi, S., Yamazaki, R., Teshima, J. \& Uenishi, K. (1973) Proc. Nat. Acad. Sci. USA, 70, 3526-3530.

198. Brostrom, C. O., Huang, Y. C., Breckenridge, B. M. \& Wolff, D. J. (1975) Proc. Nat. Acad. Sci. USA 72, 64-68.

199. Günther, T., Schmalbeck, J. \& Merker, H. J. (1973) Z. Klin. Chem. Klin. Biochem. 11, 233-236.

200. Averdunk, R., Ostapowicz, B. \& Günther, T. (1975) Z. Klin. Chem. Klin. Biochem. 13, 361-366.

201. Friedmann, N. \& Park, C. R. (1968) Proc. Nat. Acad. Sci. USA $61,504-508$.

202. Mazzocco, V. E., Lizzarralde, G., Flink, E. B. \& Jones, J. E. (1966) Proc. Soc. Exp. Biol. Med. 123, 403-408.

203. Günther, T. \& Averdunk, R. (1976) J. Clin. Chem. Clin. Biochem. 14, 365-371.

204. Freude, K. A., Zieve, F. J. \& Zieve, L. (1978) J. Nutrit. $108,1635-1641$.

205. Fuller, R. W. (1973) Fed. Proc. Fed. Am. Soc. Exp. Biol. $32,1772-1781$.

206. Günther, T., Ising, H. \& Merker, H. J. (1978) J. Clin. Chem. Clin. Biochem. 16, 293-297.

207. Chesley, L. C. \& Tepper, I. (1958) J. Clin. Invest. 37, 1362-1372.

208. Mordes, J. P. \& Wacker, W. E. C. (1978) Pharmacol. Rev. $29,273-300$.

209. Del Castillo, J. \& Engbaek, L. (1954) J. Physiol. (London) $124,370-384$.

210. Hutter, O. F. \& Kostial, K. (1954) J. Physiol. (London) $124,234-241$.

211. Jenkinson, D. H. (1957) J. Physiol. (London) 138, 434-444.

212. Stanbury, J. B. (1948) J. Pharmacol. Exp. Ther. 93, $52-62$.

213. Kirpekar, S. M. \& Misu, Y. (1967) J. Physiol. (London) 188, 219-234.

214. Lishajko, F. (1970) Acta Phy siol. Scand. 79, 575-584.

215. von Euler, U. S. \& Lishajko, F. (1973) Acta Physiol. Scand. $89,415-422$.

216. Bohr, D. F. (1964) Can. Med. Assoc. J. 90, 174-179.

217. Viveros, H. \& Somjen, G. G. (1968) Experientia, 24, 457-459.
Professor Dr. H. Ebel Institut für Klinische Physiologie Klinikum Steglitz der Freien Universität Berlin Hindenburgdamm 30 D-1000 Berlin 45 